\title{
Inorganic pollutants in edible grasshoppers (Ruspolia nitidula) of Uganda and their major public health implications
}

\author{
Keneth Iceland Kasozi ${ }^{1}$, Catherine Namazi ${ }^{2}$, Elizabeth Basemera ${ }^{3}$, \\ Collins Atuheire ${ }^{4,5}$, Ambrose Odwee ${ }^{4}$, Samuel Majalija ${ }^{3}$, John N Kateregga ${ }^{3}$
}

1. Department of Physiology, Faculty of Biomedical Sciences, Kampala International University Western Campus, Box 71, Bushenyi, Uganda.

2. School of Pharmacy, Kampala International University Western Campus, Box 71, Bushenyi, Uganda.

3. Department of Pharmacy and Comparative Medicine, School of Veterinary Medicine and Animal Resources, College of Veterinary Medicine, Makerere University, Box 7062, Kampala, Uganda.

4. Department of Public Health, School of Allied Health, Kampala International University Western Campus, Box 71, Bushenyi, Uganda.

5. Department of Health Sciences and Special Education, Africa Renewal University, Kampala.

\begin{abstract}
Background: Inorganic contamination of food products is associated with adverse health effects, however, information on grasshoppers in Africa is sparse. The objective of the study was to determine antioxidant, heavy metal and food safety status of edible grasshoppers of Uganda.

Methods: A cross-sectional study was conducted in central and southwestern Uganda, in which a questionnaire was administered to grasshopper harvesters. Grasshopper samples were collected from each harvesting point and analyzed in the laboratory for antioxidant and heavy metal content i.e. Lead (Pb), Chromium (Cr), Zinc ( $\mathrm{Zn}$ ) and Cadmium (Cd) using atomic absorbance spectrometric (AAS) method on the heads and abdomen of the insects.

Results: Major antioxidants were Catalase $>$ Glutathione $>$ Glutathione peroxidase. In addition concentrations of heavy metals were in the order of $\mathrm{Pb}>\mathrm{Cr}>\mathrm{Zn}>\mathrm{Cd}$ in the heads and abdomens of the grasshoppers. $\mathrm{Pb}$ concentrations were found to be higher in the heads than the abdomens and the carcinogenic potential of the grasshoppers was over 10 times over the recommended levels. Grasshoppers were found not to be safe especially in children due to their small body weight in comparison to adults.
\end{abstract}

Conclusion: $\mathrm{Pb}$ poisoning in the Ugandan children would be propagated through contaminated grasshoppers.

Keywords: "Ecotoxicology," Food Safety," "Metals in Insects," "Nutritional Toxicology, Pb poisoning, Uganda.

DOI: https://dx.doi.org/10.4314/ahs.v19i3.44

Cite as: Kasozi KI, Namazi C, Basemera E, Atubeire C, Odwee A, Majalija S, Kateregga JN. Inorganic pollutants in edible grasshoppers (Ruspolia nitidula) of Uganda and their major public health implications. Afri Health Sci. 2019;19(3): 2679-2691. bttps:/ I dx.doi.org/10.4314/ahs.v19i3.44

\section{Introduction}

Environmental pollution is a major public health threat that is currently affecting developing countries the most, thus creating a lot of strain on the already crippled

\section{Correspondence author: \\ Keneth Iceland Kasozi, \\ Department of Physiology, \\ Faculty of Biomedical Sciences, \\ Kampala International University \\ Western Campus, Box 71, Bushenyi, Uganda. \\ Email: kicelandy@gmail.com}

healthcare system in a majority of these countries ${ }^{1,2}$. This has been a result of the rapid economic and agricultural growth, leading to an increased usage of inorganiclements of industrial origin that had never been used before. For example, the use of herbicides, acaricides, and insecticides is associated with modern methods of farming although their safety continues to be a subject of major intellectual debate ${ }^{3-5}$. The herbicides and pesticides that are commonly used by farmers contain several elements such as lead $(\mathrm{Pb})$, zinc $(\mathrm{Zn})$, cadmium $(\mathrm{Cd})$, iron $(\mathrm{Fe})$, chromium $(\mathrm{Cr})$ and manganese $(\mathrm{Mn})^{6}$. Heavy metal contamination of soils as a result of human activity is a real threat due to the ability of the plants to absorb these molecules, (C) 2019 Kasozi et al. Licensee African Health Sciences. This is an Open Acresticted use, distribution, and reproduction in any medium, provided the
License (https://creativecommons.org/licenses/BY/4.0), which permits unrestricte original work is properly cited. 
the heavy metals can then enter the food chain ${ }^{6,7}$. This level of contamination is a result of poor usage or lack of clear policies to monitor usage and disposal of farm waste.

In Africa, heavy metal contamination of major water bodies has been demonstrated to be a threat ${ }^{8}$, although the mechanism through which such contamination is propagated has not been fully investigated. In Uganda, population exposure to heavy metals as a result of human activities in mining and agricultural sites has been demonstrated ${ }^{9}$. In addition, attention has been placed on fish associated with the fresh water lakes of Uganda ${ }^{10,11}$. Heavy metal load in livestock products of Uganda have been shown to have higher than the recommended levels, thus posing a major public health risk ${ }^{12-14}$. This means that animal products from Uganda still have a hurdle in accessing international markets, and this continues to be complicated by a lack of continuous surveillance data on major food products. Among these products, are grasshoppers, whose commercialization has been recommended by several scientists ${ }^{15,16}$. Eating of insects acts as an alternative cheap source of food and reduces environmental pollution following biomass transformation in $\operatorname{man}^{17}$. In Uganda, grasshoppers are a source of economic livelihood ${ }^{15}$ and a recent study in Uganda showed that the edible grasshoppers (Ruspolia nitidula) are nutritious ${ }^{16}$, although information on chemical hazard food safety is sparse. This would be highly important since the high antioxidant activity, accumulated from the forage eaten can be affected by levels of heavy metals in the tissues ${ }^{18-20}$. Bearing in mind that grasshoppers have been shown to have the ability to concentrate heavy metals in their exoskeleton especially the heads ${ }^{21,22}$, questions on food safety need to be addressed before they can be branded as safe foods for national and international consumption. Bioaccumulation of heavy metals especially of $\mathrm{Pb}, \mathrm{Zn}, \mathrm{Cd}$, and $\mathrm{Cr}$ have been shown to a major threat that would ultimately disrupt physiological processes in humans, just as it does in the insects ${ }^{23,24}$. The objective of the current study was to determine antioxidant activity, heavy metal load, and investigate food safety of grasshoppers that are eaten in Uganda.

\section{Materials and methods Study design}

This was a cross-sectional study conducted in insect feeding communities of Central and Southwestern Uganda. Raw grasshoppers (Ruspolia nitidula) were collected purposively and by convenience method during November to December 2016 in southwestern (Bushenyi, Sheema and Mbarara districts) and Central (Wakiso, Kampala and Mukono districts) regions of Uganda as shown in Figure 1. Sampling was done to ensure that both rural $(\mathrm{N}=30)$ and urban $(\mathrm{N}=30)$ settings contributed to the homogenized sample pool in each district. Convenience and purposive sampling were conducted and samples were acquired following harvesting by the community in each major center in both peri-urban (towns) and rural (villages) areas. These were then transported to the Department of Physiology laboratory using a cool box with ice packs and subsequently stored at $-20^{\circ} \mathrm{C}$ for laboratory analysis. In the communities, a semi-structured questionnaire was administered to 239 grasshopper gatherers who were chosen randomly. They provided responses on their experience in the grasshopper business, history of professional training, health complications acquired during their stay in this occupation, quantity of grasshoppers eaten by their homesteads, education background, hygiene status, and biosafety measures implemented while at work.

In the laboratory, each grasshopper was separated into the head and abdomen segments. These were subsequently homogenized for biochemical and heavy metal analysis. Samples were separated according to districts, 1 gram of each sample was then weighed and placed into a homogenizer with $0.1 \mathrm{M}$ phosphate buffer saline. The mixture was then centrifuged at $15000 \mathrm{rpm}$ for 5 minutes and the supernatant was placed in sterile Eppendorfs for analysis.

\section{Antioxidant determination}

Glutathione peroxidase (GPx) was determined according to standard methods 25. Glutathione (GSH) was determined according to standard methods 26 and absorbance was read at $405 \mathrm{~nm}$. Catalase (CAT) was determined according to standard methods 27 since these were small animal samples and absorbance was read at $580 \mathrm{~nm}$, after which standard curves were made. 


\section{Heavy metal determination}

Following homogenization, approximately $1 \mathrm{~g}$ of the head and abdomen from each sample was subjected to heavy metal analysis i.e. Lead (Pb), Cadmium (Cd), Chromium $(\mathrm{Cr})$ and Zinc $(\mathrm{Zn})$ by using standard spectrometric methods $^{28}$. Wet digestion of the samples i.e. heads and abdomens were done using $30 \mathrm{ml}$ of nitric acid at $150^{\circ} \mathrm{C}$ for 45 minutes. $2 \mathrm{ml}$ of hydrogen peroxide were added to further the digestion after the solution reduced to about $10 \mathrm{ml}$. The entire solution was then made up to $30 \mathrm{ml}$ with deionized water and transferred to a plastic bottle ready for analysis. The sample solution was analyzed with an atomic absorption spectrophotometer (AAS), model Perkin Elmer 2380 (Artisan Group Company, Champaign, IL, USA). Working standards of $0.2 \mathrm{ppm}, 0.5$ ppm, $1 \mathrm{ppm}, 2 \mathrm{ppm}$, and $5 \mathrm{ppm}$ were prepared from a stock solution of 1000 ppm (Pb, Cd, Cr, and Zn). Standard curves were generated as described previously ${ }^{14}$, and these were used to determine the concentration of the inorganic compounds in each sample.

\section{Food safety analysis}

This was done using methods as previously described ${ }^{14}$ where the Estimated Daily Intake (EDI) was calculated using the equation below:

$\mathrm{EDI}=(\mathrm{C} \times \mathrm{IR}) / \mathrm{BW}$ where, $\mathrm{C}=$ concentration of the metal $(\mathrm{mg} / \mathrm{kg})$, IR = ingestion $(\mathrm{g} / \mathrm{kg})$ rate for grasshoppers in each region were got after calculating quantity eaten each day. The IR was calculated using the questionnaire from which amount eaten per day was calculated since there was no available epidemiological data on this in Uganda. The mean weight (BW) for adults and children in Uganda of $60.7 \mathrm{~kg}$ and $20.5 \mathrm{~kg}$ respectively were used in line with global projections ${ }^{29}$.

\section{Cancer risk}

In food products, the US EPA cancer risk regulatory acceptable levels are in the range of $1 \times 10-6$ to $1 \times 10-4$. Incremental lifetime cancer risk (ILCR) was obtained using the oral Cancer Slope Factor (CSF), and the US EPA reference CSF values ${ }^{30}$ were used due to limited reference values from Africa. The CSF was defined as the risk produced by a lifetime average dose of $1 \mathrm{ppm} / \mathrm{BW} /$ day and its contaminant specific. For $\mathrm{Pb}, \mathrm{Zn}, \mathrm{Cr}$, and $\mathrm{Cd}$, the corresponding CSFs used are 0.0085; 0.0001; 41 and 6.3 $\mathrm{ppm} / \mathrm{day}$, thus the ILCR was calculated for each metal using this equation:
ILCR $=\mathrm{CDI} * \mathrm{CSF}$ where CDI is the chronic daily intake of chemical $(\mathrm{mg} / \mathrm{kg} /$ day) and it represents the lifetime average daily dose of exposure to a chemical ${ }^{14}$.

$\mathrm{CDI}=(\mathrm{EDI} * \mathrm{EFr} * \mathrm{EDtot}) / \mathrm{AT}$ where, EDI was the estimated daily intake of a metal; EFr was exposure frequency (365 days/year); EDtot was the exposure duration 58.65 years (lifetime average for Ugandans; and AT = was the period of exposure for non-carcinogenic effects, and 70 year lifetime for carcinogenic effects (i.e. 70 years $* 365$ days/year $)^{14}$. The cancer risk was taken to be a summation of exposure to different inorganic pollutants in the grasshoppers $^{14}$.

\section{Non-cancer risks}

These are assumed to exhibit a threshold below which no adverse effects are expected to be observed. As such, non-carcinogenic health hazards are evaluated by the target hazard quotient (THQ) using the equation below:

THQ $=\mathrm{CDI} / \mathrm{RfD}$ Where; CDI = exposure dose obtained and RfD is the oral reference dose of the contaminant ${ }^{14}$. The RfD was an estimation of the maximum permissible risk on the human population through daily exposure, taking into consideration a sensitive group during a lifetime. The $\mathrm{RfD}$ values for $\mathrm{Pb}, \mathrm{Cd}, \mathrm{Cr}$ and $\mathrm{Zn}$ that were used are 0.004, 0.001, 1.5 and 0.3 respectively. Exposure to multiple contaminants results in additive and interactive effects therefore to evaluate the effect of multiple exposures, the chronic hazard index which was the sum of all the hazard ratios (THQ) was calculated for individual contaminants for oral ingestion. The $\mathrm{HI}$ is assumed safe in a population when the HI $<1$ and it's a measure of concern when the $1<\mathrm{HI}<5$.

\section{Statistical analysis}

Qualitative data from the questionnaire were coded and entered into SPSS Version 20 for analysis, subjected to normality testing, and parametric tests were chosen. Chisquare, Fisher's test, and 95\% confidence intervals were determined. In addition, quantitative data from laboratory analysis of the samples was analyzed with Graph Pad Prism Version 6. Turkey's multiple comparison tests was conducted on metal concentrations and information was displayed inform of means \pm SEM. In addition, a one-sample t-test was conducted during food safety analysis and significance was set at 95\% confidence and superscripts were used to indicate significant differences. Inferences were made in comparison to international ref- 
erence standards to demonstrate the public health risk for each contaminant.

\section{Results}

The mean ( \pm SEM) age of those involved in the grasshopper industry was found to be $30.96( \pm 0.62)$ and 31.93 $( \pm 0.80)$ years from both the peri-urban and rural study population. The population also showed a low level of experience in any food industry and levels of grasshoppers eaten were relatively the same in both peri-urban and rural settings. No significant differences were seen $(\mathrm{P}$ $>0.05$ ) amongst age, experience in the food processing business and amount of grasshoppers consumed in the study population that would be associated with the different regions in Uganda as shown in Table 1.

\section{Table 1 Mean age, experience and amount of grasshoppers eaten in peri-urban and urban Uganda}

\begin{tabular}{lllcc}
\hline Independent Variable & $\begin{array}{l}\text { Dependent } \\
\text { Variable }\end{array}$ & $\mathrm{N}$ & Mean \pm SEM & P-value \\
\hline Age (Yrs.) & Peri-urban & 122 & $30.96 \pm 0.62$ & .340 \\
& Rural & 117 & $31.93 \pm 0.80$ & \\
Experience in Food Industry & Peri-urban & 122 & $1.36 \pm 0.14$ & .837 \\
(yrs.) & Rural & 117 & $1.31 \pm 0.19$ & \\
Amount consumed in study & Peri-urban & 122 & $345.86 \pm 28.33$ &. \\
population (g) & Rural & 117 & $310.69 \pm 29.90$ & .404 \\
\hline
\end{tabular}

\section{KEY: T-test conducted.}

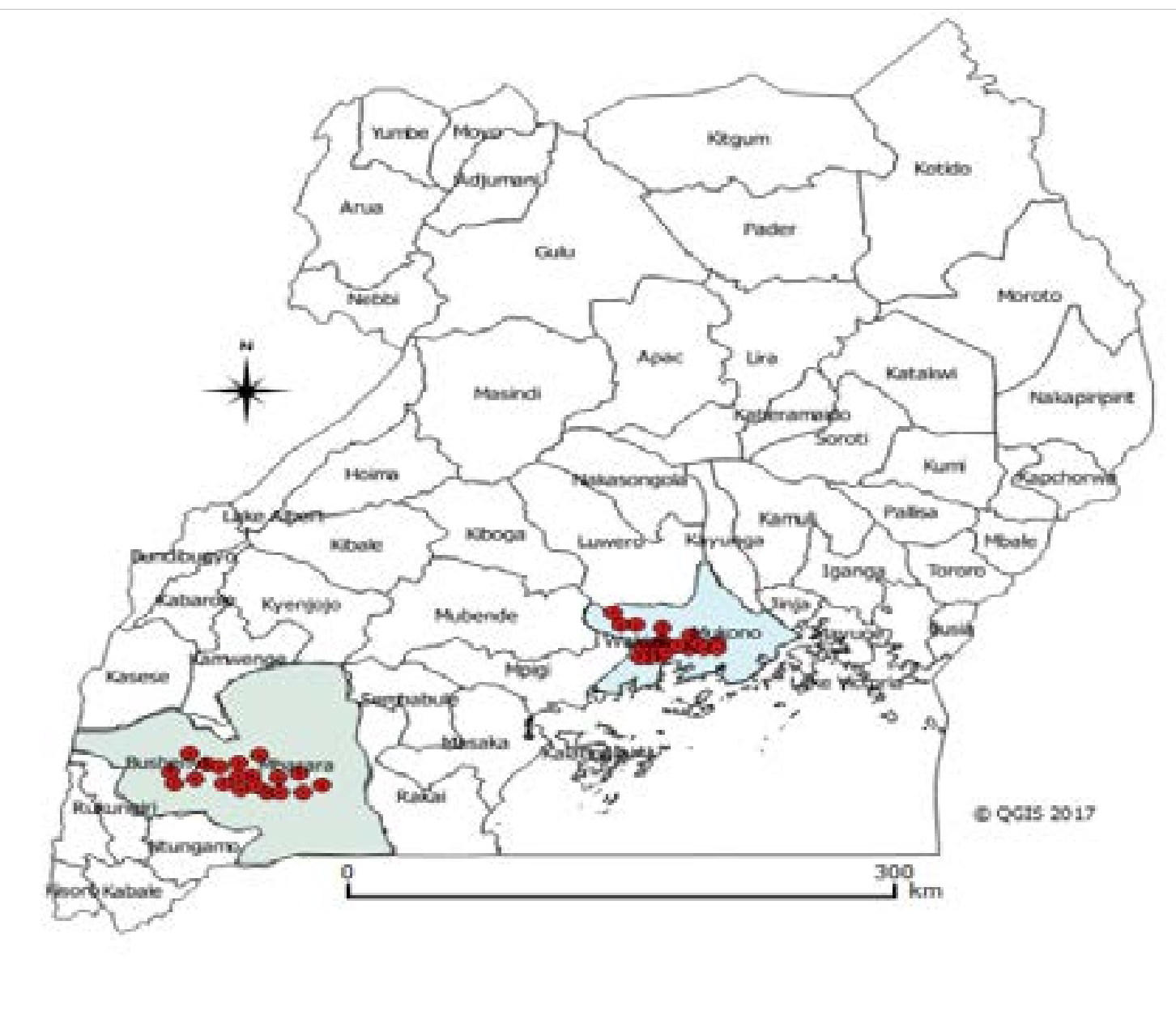

Figure 1: Map of Uganda showing study districts where the edible grasshoppers (Ruspolia nitidula) were collected 
The study population composed of mainly the male gen$\operatorname{der}(170 / 239)$ and were in favor of the male population showing that the business is dominated by men from Central Uganda (101/120). In the population, a majority of the population (136/239) didn't have a basic level of education and of these 97/120 were from central Uganda with only a primary education, demonstrating that a major part of the population in the industry are illiterate. During grasshopper harvesting, a majority (128/239) did not use appropriate materials for collecting the grasshoppers, irregularly cleaned the work items $(158 / 239)$ of which 104/120 were from central Uganda. The community didn't process the grasshoppers effectively (176/239) and a majority of these were from central Uganda and lacked facilities to control the temperatures (179/239). In addition, very high significant differences were seen $(\mathrm{P}$ $<0.05)$ in the population from central and southwestern Uganda as shown in Table 2.

Table 2 Frequency (percentage) of major socio-economic and food safety measures amongst grasshopper handlers in Uganda

\begin{tabular}{|c|c|c|c|c|c|c|}
\hline \multirow[t]{3}{*}{ Variable } & & \multicolumn{4}{|c|}{ Frequency (\%) of participants response from each region } & \multirow{3}{*}{ P-value } \\
\hline & & \multirow[t]{2}{*}{ Central } & \multirow[t]{2}{*}{ Southwestern } & \multicolumn{2}{|r|}{ Total } & \\
\hline & & & & Value & 95\% CI: LL; UL & \\
\hline \multirow[t]{2}{*}{ Sex } & Female & $19(15.83)$ & $50(42.02)$ & $69(28.87)$ & $23.21 ; 35.06$ & $0.00^{\mathrm{a}}$ \\
\hline & Male & $101(84.17)$ & $69(57.98)$ & $170(71.13)$ & $64.94 ; 76.79$ & \\
\hline \multirow[t]{2}{*}{ Education level } & $\leq$ Primary & $97(80.83)$ & $39(32.77)$ & $136(56.90)$ & $50.36 ; 63.27$ & \multirow[t]{2}{*}{$0.00^{\mathrm{a}}$} \\
\hline & $\geq$ Secondary & $23(19.17)$ & $80(67.23)$ & $103(43.10)$ & $36.73 ; 49.64$ & \\
\hline \multirow{2}{*}{$\begin{array}{l}\text { Harvesting } \\
\text { Material }\end{array}$} & Curved & $26(21.67)$ & $85(71.43)$ & $111(46.44)$ & $39.99 ; 52.79$ & \multirow[t]{2}{*}{$0.00^{\mathrm{a}}$} \\
\hline & Tampering & $94(78.33)$ & $34(28.57)$ & $128(53.56)$ & $47.01 ; 60.01$ & \\
\hline \multirow[t]{2}{*}{ Cleaning Done } & Regular & $16(13.33)$ & $65(54.62)$ & $81(33.89)$ & $27.91 ; 40.27$ & \multirow[t]{2}{*}{$0.00^{\mathrm{a}}$} \\
\hline & Irregular & $104(86.67)$ & 54(45.38) & $158(66.11)$ & $59.73 ; 72.09$ & \\
\hline \multirow{2}{*}{$\begin{array}{l}\text { Processing after } \\
\text { Harvest }\end{array}$} & Cold Treatment & $1(0.83)$ & $62(52.10)$ & $63(26.36)$ & $20.89 ; 32.43$ & \multirow[t]{2}{*}{$0.00^{\mathrm{b}}$} \\
\hline & Open Air & $119(99.17)$ & $57(47.90)$ & $176(73.64)$ & $67.57 ; 79.11$ & \\
\hline \multirow[t]{2}{*}{ Biosafety Gear } & $\begin{array}{l}\text { Harvesting } \\
\text { clothing }\end{array}$ & $68(56.67)$ & $91(76.47)$ & $159(66.53)$ & $60.16 ; 72.48$ & \multirow[t]{2}{*}{$0.00^{\mathrm{a}}$} \\
\hline & Casual clothing & $52(43.33)$ & $28(23.53)$ & $80(33.47)$ & $27.52 ; 39.84$ & \\
\hline \multirow[t]{2}{*}{$\begin{array}{l}\text { Physiological } \\
\text { status }\end{array}$} & $\begin{array}{l}\text { Infection from } \\
\text { work }\end{array}$ & $8(6.67)$ & $66(55.46)$ & $74(30.96)$ & $25.16 ; 37.24$ & \multirow[t]{2}{*}{$0.00^{\mathrm{a}}$} \\
\hline & Healthy & $112(93.33)$ & $53(44.54)$ & $165(69.04)$ & $62.76 ; 74.84$ & \\
\hline \multirow{3}{*}{$\begin{array}{l}\text { Temperature } \\
\text { and Hygiene } \\
\text { Control }\end{array}$} & Facilities present & $0(0.00)$ & $58(48.74)$ & $58(24.47)$ & $19.14 ; 30.46$ & \multirow[t]{2}{*}{$0.00^{\mathrm{b}}$} \\
\hline & No Facilities & $120(100)$ & $59(51.26)$ & $179(75.53)$ & $69.54 ; 80.86$ & \\
\hline & & & & & & \\
\hline \multirow{2}{*}{$\begin{array}{l}\text { Traceability of } \\
\text { Products }\end{array}$} & Documentation & $0(0.00)$ & $60(50.42)$ & $60(25.10)$ & $19.74 ; 31.10$ & \multirow[t]{2}{*}{$0.00^{\mathrm{b}}$} \\
\hline & Impossible & $120(100)$ & $59(49.58)$ & $179(74.90)$ & $68.90 ; 80.26$ & \\
\hline \multirow[t]{2}{*}{ Locality setting } & Peri-urban & $63(52.50)$ & $59(49.58)$ & $122(51.05)$ & $44.52 ; 57.55$ & \multirow[t]{2}{*}{$0.65^{\mathrm{a}}$} \\
\hline & Rural & $57(47.50)$ & $60(50.42)$ & $117(48.95)$ & $42.45 ; 55.48$ & \\
\hline
\end{tabular}

Self-reported infections $(36.0 \%)$ that had developed due to the grasshopper harvesting period were found to be most prevalent in rural workers. Moreover, the same population that was facing infections was found to have a low work experience in the business as compared to the more senior population as shown in Figure 2. The mean age in both the employee and employer population was found to be equally the same, although major variations existed in the employer population as shown in Figure 3. 


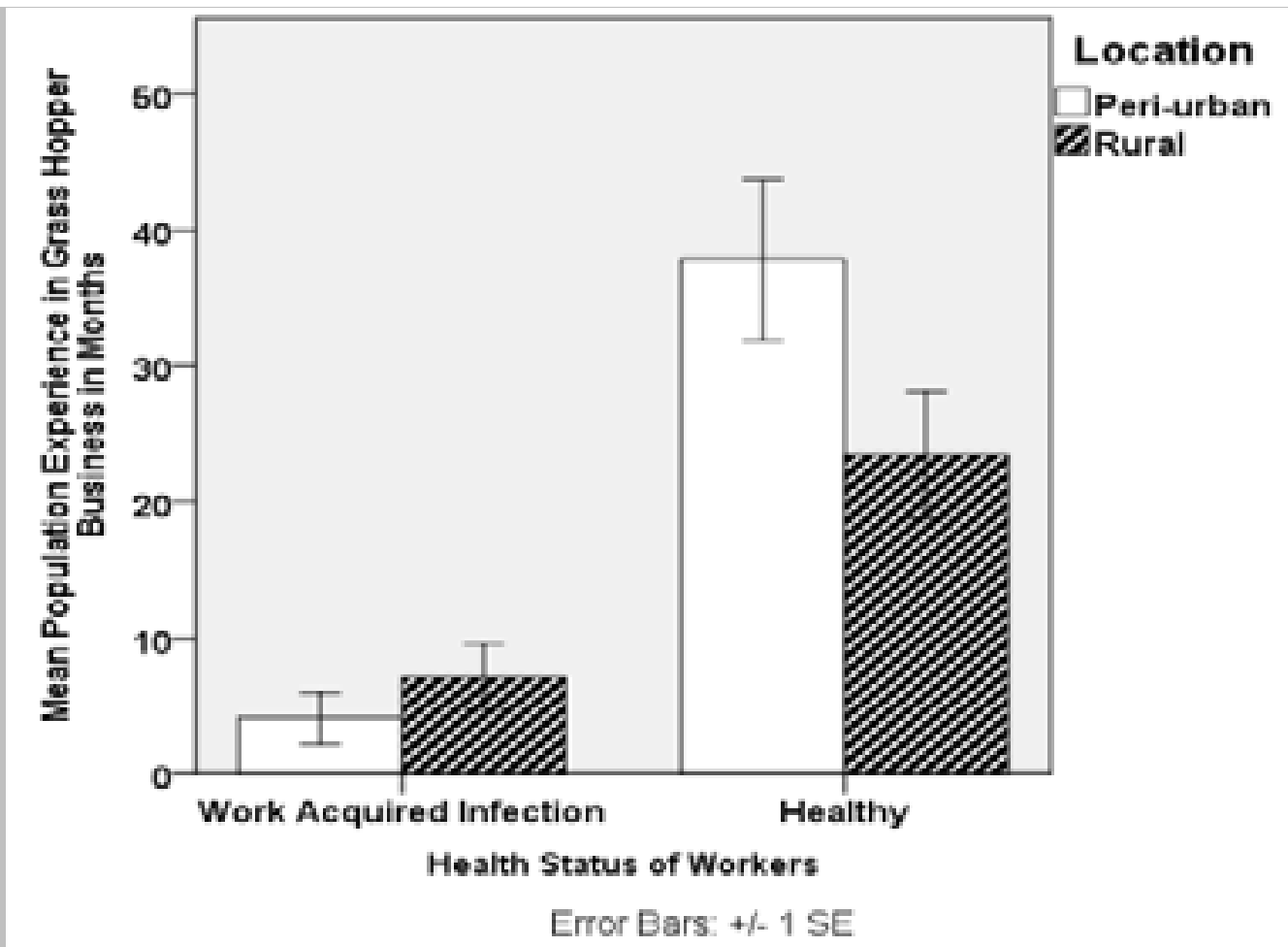

Figure 2: Grasshoppers physiological effects on workers from different locations and their experience in handling grasshoppers.

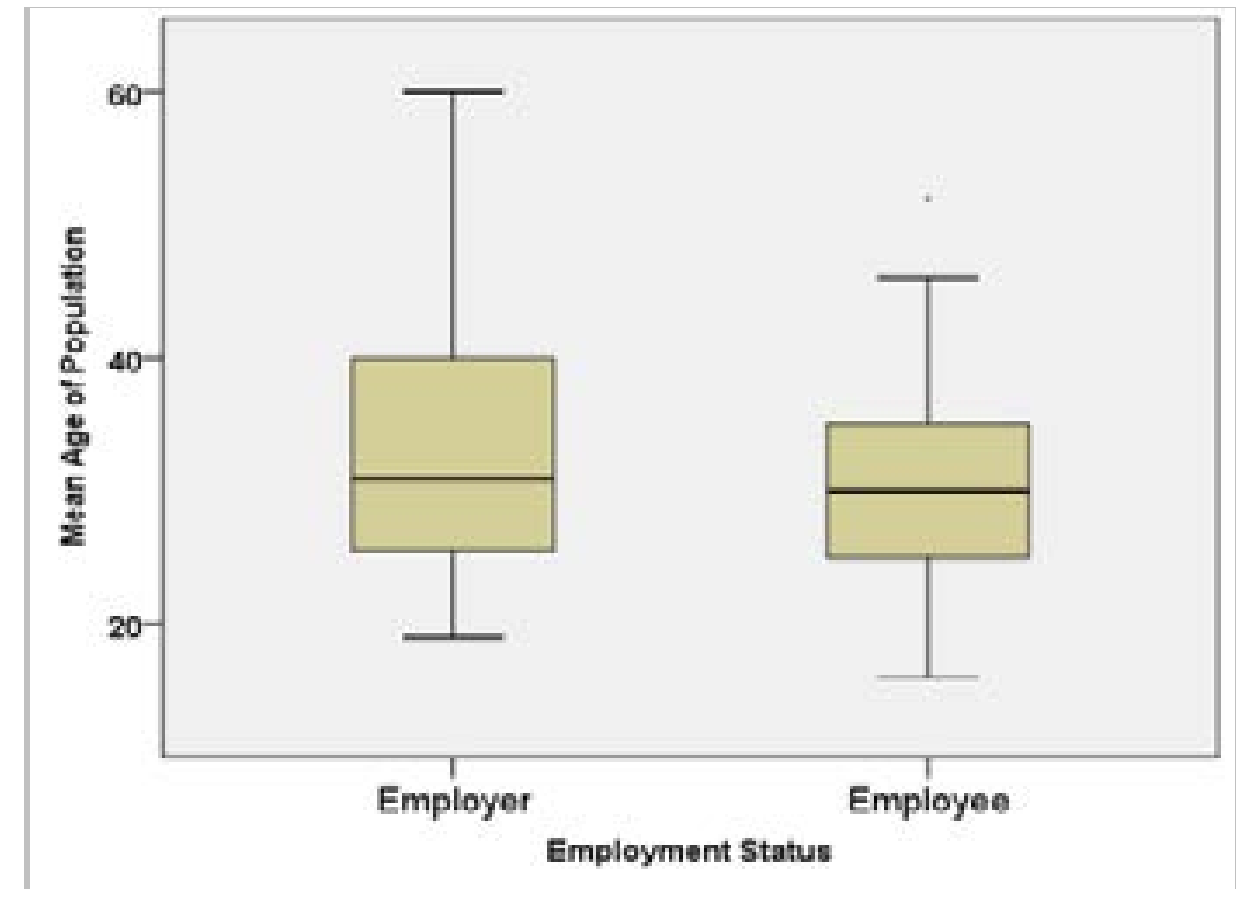

Figure 3: Age distribution and employment status in grasshopper business community. 


\section{Antioxidants in grasshoppers of Uganda}

Laboratory analysis showed high levels of catalase in the heads and these concentrations were significantly highest in rural isolates from the Central region $(\mathrm{P}<0.05)$ as shown in Table 3. Grasshopper catalase concentrations were highest in head samples from peri-urban areas. In addition, significant differences $(\mathrm{P}<0.05)$ were found in catalase concentrations in both the heads and abdomen from both isolation centers.

Table 3 Antioxidants concentrations in grasshoppers from different locations of Uganda.

\begin{tabular}{|c|c|c|c|c|c|}
\hline \multirow{3}{*}{$\begin{array}{l}\text { Antioxidant } \\
((\mu \mathrm{M} / \mathrm{g}))\end{array}$} & \multirow[b]{3}{*}{$\mathrm{N}$} & \multicolumn{2}{|c|}{ Peri-Urban } & \multicolumn{2}{|c|}{ Rural } \\
\hline & & Head & Abdomen & Head & Abdomen \\
\hline & & \multicolumn{4}{|c|}{ Concentrations \pm SEM } \\
\hline \multicolumn{6}{|c|}{ Central Uganda } \\
\hline CAT & 3 & $379.85 \pm 138.77^{\text {a }}$ & $173.87 \pm 42.06^{b}$ & $561.93 \pm 20.99^{a}$ & $235.99 \pm 49.19^{b}$ \\
\hline GPx & 3 & $0.65 \pm 0.05^{\mathrm{a}}$ & $0.38 \pm 0.06^{\mathrm{a}}$ & $1.52 \pm 0.18^{\mathrm{a}}$ & $0.40 \pm 0.12^{\mathrm{a}}$ \\
\hline GSH & 3 & $92.40 \pm 36.92^{\mathrm{a}}$ & $32.05 \pm 14.95^{\mathrm{a}}$ & $61.14 \pm 23.83^{\mathrm{a}}$ & $15.89 \pm 2.06^{\mathrm{a}}$ \\
\hline \multicolumn{6}{|c|}{ Southwestern Uganda } \\
\hline CAT & 3 & $374.17 \pm 6.97^{a}$ & $149.51 \pm 40.57^{b}$ & $361.18 \pm 74.76^{a}$ & $118.34 \pm 29.69^{b}$ \\
\hline GPx & 3 & $0.40 \pm 0.04^{\mathrm{a}}$ & $0.13 \pm 0.03^{\mathrm{a}}$ & $0.30 \pm 0.12^{\mathrm{a}}$ & $0.07 \pm 0.03^{\mathrm{a}}$ \\
\hline GSH & 3 & $32.81 \pm 12.54^{a}$ & $10.61 \pm 3.91^{\mathrm{a}}$ & $20.50 \pm 2.34^{a}$ & $8.50 \pm 2.06^{\mathrm{a}}$ \\
\hline
\end{tabular}

\section{Heavy metals in grasshoppers of Uganda}

Significantly high concentrations of $\mathrm{Pb}(\mathrm{P}<0.05)$ were found to be common in grasshopper samples from the rural than peri-urban areas of Central Uganda. Similarly, there was a significant difference in the mean $\mathrm{Pb}$ concentrations in the heads compared to the abdomen of these grasshoppers from the same locality. Furthermore, concentrations of $\mathrm{Zn}$ were found to be elevated although no statistical differences were seen from the different body parts in the samples from the different locations. In southwestern Uganda, significantly high concentrations of $\mathrm{Pb}(\mathrm{P}<0.05)$ were found primarily in the heads of grasshoppers collected from both peri-urban and rural settings, while low concentrations of $\mathrm{Pb}$ were found in the abdomens. In addition, high concentrations of $\mathrm{Zn}$ and $\mathrm{Cr}$ were observed in the head grasshopper samples from rural communities as shown in Table 4. The study also showed that very high concentrations of all the heavy metals especially $\mathrm{Pb}$ are concentrated in the heads while low levels are concentrated in the abdomens of the grasshoppers. Concentrations of $\mathrm{Cr}$ and $\mathrm{Zn}$ in all grasshopper samples from both central and southwestern Uganda were low as shown in Table 4. 
Table 4: Heavy metal concentrations in grasshoppers from different locations of Uganda

\begin{tabular}{|c|c|c|c|c|c|}
\hline \multirow{2}{*}{$\begin{array}{l}\text { Heavy } \\
\text { Metals }\end{array}$} & \multirow[b]{2}{*}{$\mathrm{N}$} & \multicolumn{2}{|c|}{ Peri-urban } & \multicolumn{2}{|c|}{ Rural } \\
\hline & & Heads & Abdomen & Heads & Abdomen \\
\hline & & \multicolumn{4}{|c|}{ Concentrations \pm SEM (ppm) } \\
\hline \multicolumn{6}{|c|}{ Central Uganda } \\
\hline $\mathrm{Pb}^{*}$ & 3 & $307.11 \pm 62.07^{\mathrm{a}}$ & $150.95 \pm 38.91^{\mathrm{a}}$ & $455.55 \pm 90.30^{\mathrm{a}}$ & $140.81 \pm 93.76^{b}$ \\
\hline $\mathrm{Zn}$ & 3 & $137.06 \pm 22.62^{\mathrm{a}}$ & $117.87 \pm 17.95^{\mathrm{a}}$ & $134.63 \pm 16.93^{\mathrm{a}}$ & $87.89 \pm 8.96^{\mathrm{a}}$ \\
\hline $\mathrm{Cr}$ & 3 & $166.93 \pm 33.94^{a}$ & $53.97 \pm 6.69$ & $190.50 \pm 54.24^{\mathrm{a}}$ & $90.01 \pm 22.67^{\mathrm{a}}$ \\
\hline $\mathrm{Cd}$ & 3 & $0.12 \pm 0.12^{\mathrm{a}}$ & $0.07 \pm 0.04^{a}$ & $0.16 \pm 0.05^{\mathrm{a}}$ & $0.02 \pm 0.02^{\mathrm{a}}$ \\
\hline \multicolumn{6}{|c|}{ Southwestern Uganda } \\
\hline $\mathrm{Pb}$ & 3 & $150.56 \pm 97.56^{a}$ & $39.10 \pm 39.10^{a}$ & $102.88 \pm 102.88^{a}$ & $78.62 \pm 78.62^{a}$ \\
\hline $\mathrm{Zn}$ & 3 & $92.72 \pm 21 .{ }^{82 a}$ & $85.01 \pm 32.51^{\mathrm{a}}$ & $113.95 \pm 21.83^{\mathrm{a}}$ & $91.07 \pm 19.67^{\mathrm{a}}$ \\
\hline $\mathrm{Cr}$ & 3 & $105.76 \pm 28.30^{a}$ & $38.13 \pm 22.91^{\mathrm{a}}$ & $112.51 \pm 39.95^{\mathrm{a}}$ & $55.18 \pm 9.91^{\mathrm{a}}$ \\
\hline $\mathrm{Cd}$ & 3 & $0.03 \pm 0.03^{\mathrm{a}}$ & $0.02 \pm 0.01^{\mathrm{a}}$ & $0.06 \pm 0.03^{\mathrm{a}}$ & $0.06 \pm 0.03^{\mathrm{a}}$ \\
\hline
\end{tabular}

Estimated daily Intake (EDI) for grasshoppers in Uganda

The EDI showed that lead ingested was beyond the recommended levels in food products. In particular, lead ingestion levels are higher in grasshoppers from the Central region than the southwestern region of Uganda. Also, significant variations existed in EDI of $\mathrm{Pb}$ in the heads and abdomen, showing that the risk possessed by consumption of heads of grasshoppers was two to three times greater than that from ingestion of the abdomen as shown in Table 5. Furthermore, EDI in children was three fold higher than that in adults, showing that children are more at risk of $\mathrm{Pb}$ toxicity.

Table 5 Estimated Daily Intake of Heavy Metals in Grasshoppers of Uganda.

\begin{tabular}{|c|c|c|c|c|c|}
\hline \multirow{3}{*}{$\begin{array}{l}\text { Heavy } \\
\text { Metals } \\
\text { Consumed }\end{array}$} & \multirow{2}{*}{ TDI } & \multicolumn{2}{|c|}{ Peri-urban } & \multicolumn{2}{|c|}{ Rural } \\
\hline & & Heads & Abdomen & Heads & Abdomen \\
\hline & \multicolumn{5}{|c|}{ Concentration in $\mathrm{mg} / \mathrm{kg} /$ day } \\
\hline \multicolumn{6}{|c|}{ Central Uganda } \\
\hline $\mathrm{Pb}$ & 3.57 & $67.01^{a *}$ & $32.93^{a *}$ & $99.39 *$ & $30.72^{a *}$ \\
\hline $\mathrm{Zn}$ & 1000 & $29.89^{b}$ & $25.72^{b}$ & $29.37^{\mathrm{b}}$ & $19.18^{b}$ \\
\hline $\mathrm{Cr}$ & 150 & $36.42^{b}$ & $11.78^{b}$ & $41.56^{b}$ & $19.64^{b}$ \\
\hline $\mathrm{Cd}$ & 1 & $0.026^{b}$ & $0.015^{b}$ & $0.035^{b}$ & $0.0044^{\mathrm{b}}$ \\
\hline \multicolumn{6}{|c|}{ Southwestern Uganda } \\
\hline $\mathrm{Pb}$ & 3.57 & $22.81^{a *}$ & $5.92^{\mathrm{a} *}$ & $15.59^{a *}$ & $11.91^{\mathrm{a} *}$ \\
\hline $\mathrm{Zn}$ & 1000 & $14.05^{b}$ & $12.88^{b}$ & $17.26^{b}$ & $13.80^{b}$ \\
\hline $\mathrm{Cr}$ & $150 \mathrm{~b}$ & $16.02^{b}$ & $5.78^{b}$ & $17.04^{b}$ & $8.34^{b}$ \\
\hline $\mathrm{Cd}$ & 1 & $0.0045^{b}$ & $0.003^{\mathrm{b}}$ & $0.0091^{\mathrm{b}}$ & $0.0091^{\mathrm{b}}$ \\
\hline
\end{tabular}

KEY: TDI $=$ Tolerable Daily Intake. EDI $=$ Estimated daily intake for an average in adult in Central Uganda. Asterisks indicate one sample t-test significant differences and superscripts (a,b) indicate risk level; $\mathrm{a}=$ above; $\mathrm{b}=$ below, while $*=P<0.05, * *=P<0.005$. 
Cancer risk assessment in grasshopper feeding community of Uganda

The ILCR in all the aforesaid samples were at least 100 times greater in a majority of the samples collected from either the central or southwestern regions of Uganda. In addition, the ILCR was generally two to three times higher in the head than the abdomen with lead, and chromium from each region as shown in Table 6.

Table 6: Incremental lifetime cancer risks for adults in Uganda feeding Grasshoppers.

\begin{tabular}{|c|c|c|c|c|}
\hline \multirow[t]{4}{*}{ Contaminant } & \multicolumn{2}{|c|}{ Peri-urban } & \multirow{2}{*}{$\begin{array}{c}\text { Rural } \\
\text { Heads } \\
\end{array}$} & \multirow[b]{2}{*}{ Abdomen } \\
\hline & Heads & Abdomen & & \\
\hline & \multicolumn{4}{|c|}{ Mean ILCR $\left(\times 10^{-4}\right)$} \\
\hline & \multicolumn{4}{|c|}{ Central Region } \\
\hline & \multirow{2}{*}{\multicolumn{2}{|c|}{$2.346^{\mathrm{a}}$}} & \multirow[b]{2}{*}{$7.079^{\mathrm{a}}$} & \multirow[b]{2}{*}{$2.188^{\mathrm{a}}$} \\
\hline $\mathrm{Pb}$ & & & & \\
\hline $\mathrm{Zn}$ & $2.129^{\mathrm{a}}$ & $5.423^{\mathrm{a}}$ & $2.092^{\mathrm{a}}$ & $1.366^{\mathrm{a}}$ \\
\hline $\mathrm{Cr}$ & $2.594^{a}$ & $2.483^{a}$ & $2.960^{\mathrm{a}}$ & $1.399^{\mathrm{a}}$ \\
\hline $\mathrm{Cd}$ & $0.002^{b}$ & $0.003^{b}$ & $0.002^{b}$ & $0.000^{b}$ \\
\hline SM & $9.497^{\mathrm{a}}$ & $10.255^{\mathrm{a}}$ & $12.133^{\mathrm{a}}$ & $4.953^{\mathrm{a}}$ \\
\hline \multicolumn{5}{|c|}{ Child } \\
\hline $\mathrm{Pb}$ & $14.130^{\mathrm{a}}$ & $6.945^{\mathrm{a}}$ & $20.960^{\mathrm{a}}$ & $6.479^{\mathrm{a}}$ \\
\hline $\mathrm{Zn}$ & $6.303^{a}$ & $5.423^{\mathrm{a}}$ & $6.194^{a}$ & $4.044^{\mathrm{a}}$ \\
\hline $\mathrm{Cr}$ & $7.680^{\mathrm{a}}$ & $2.483^{a}$ & $8.765^{a}$ & $4.141^{\mathrm{a}}$ \\
\hline $\mathrm{Cd}$ & $0.006^{b}$ & $0.003^{b}$ & $0.007^{b}$ & $0.001^{\mathrm{b}}$ \\
\hline SUM & $28.119^{\mathrm{a}}$ & $14.855^{\mathrm{a}}$ & $35.926^{\mathrm{a}}$ & $14.665^{\mathrm{a}}$ \\
\hline & & Southwes & & \\
\hline & & & & \\
\hline $\mathrm{Pb}$ & $1.62^{\mathrm{a}}$ & $0.422^{b}$ & $1.110^{\mathrm{b}}$ & $0.848^{b}$ \\
\hline $\mathrm{Zn}$ & $1.000^{\mathrm{b}}$ & $0.917^{b}$ & $1.229^{\mathrm{b}}$ & $0.983^{b}$ \\
\hline $\mathrm{Cr}$ & $1.141^{\mathrm{b}}$ & $0.411^{b}$ & $1.214^{b}$ & $0.595^{b}$ \\
\hline $\mathrm{Cd}$ & $0.000^{\mathrm{b}}$ & $0.000^{b}$ & $0.001^{\mathrm{b}}$ & $0.001^{\mathrm{b}}$ \\
\hline SUM & $3.766^{\mathrm{a}}$ & $1.751^{\mathrm{a}}$ & $3.554^{\mathrm{a}}$ & $2.427^{\mathrm{a}}$ \\
\hline & & & & \\
\hline $\mathrm{Pb}$ & $6.927^{\mathrm{a}}$ & $1.799^{a}$ & $4.733^{\mathrm{a}}$ & $3.617^{\mathrm{a}}$ \\
\hline $\mathrm{Zn}$ & $4.266^{\mathrm{a}}$ & $3.911^{\mathrm{a}}$ & $5.243^{\mathrm{a}}$ & $4.190^{\mathrm{a}}$ \\
\hline $\mathrm{Cr}$ & $4.866^{a}$ & $1.754^{\mathrm{a}}$ & $5.177^{\mathrm{a}}$ & $2.539^{a}$ \\
\hline $\mathrm{Cd}$ & $0.001^{b}$ & $0.001^{\mathrm{b}}$ & $0.003^{b}$ & $0.003^{b}$ \\
\hline SUM & $16.061^{\mathrm{a}}$ & $7.465^{\mathrm{a}}$ & $15.156^{a}$ & $10.349^{a}$ \\
\hline
\end{tabular}

KEY: ILCR = Incremental lifetime cancer risks; Superscripts (a, b) indicate cancer risk, a = cancer risk present, $\mathrm{b}=$ cancer risk absent.

Non-cancer risks in grasshopper eating communities of Uganda

The target hazard quotient (THQ) showed that levels of the metals are generally above 1 thus raising major health concerns. In central Uganda, the hazard index (HI) was 100 times greater than the recommended levels which were primarily due to the THQ of $\mathrm{Pb}$, however, the THQ for Cr and Cd was low levels, demonstrating the role of $\mathrm{Pb}$ contamination in grasshoppers. In southwestern Uganda, the THQ Zn, Cr, and Cd were all below one (THQ $<1$ ) demonstrating differences in the risk posed by grasshoppers from the two regions in Uganda investigated in this study.Furthermore, the HI was mainly elevated due to Pb concentrations, as shown in Table 7. 
Table 7: Target Hazard Quotients for Central Uganda.

\begin{tabular}{|c|c|c|c|c|}
\hline \multirow{4}{*}{ Contaminant } & \multicolumn{2}{|c|}{ Peri-urban } & \multicolumn{2}{|c|}{ Rural } \\
\hline & Heads & Abdomen & Heads & Abdomen \\
\hline & \multicolumn{4}{|c|}{ Mean THQ (ppm/day) } \\
\hline & \multicolumn{4}{|c|}{ Central region } \\
\hline \multicolumn{5}{|c|}{ Adult } \\
\hline $\mathrm{Pb}$ & $16.7516^{\mathrm{a}}$ & $8.2337^{\mathrm{a}}$ & $24.8484^{\mathrm{a}}$ & $7.6806^{a}$ \\
\hline $\mathrm{Zn}$ & $0.0996^{6}$ & $0.2538^{6}$ & $0.0979^{b}$ & $0.0639^{6}$ \\
\hline $\mathrm{Cr}$ & $0.0243^{b}$ & $0.0232^{b}$ & $0.0277^{\mathrm{b}}$ & $0.0131^{\mathrm{b}}$ \\
\hline $\mathrm{Cd}$ & $0.0262^{b}$ & $0.0452^{b}$ & $0.0349^{b}$ & $0.0044^{b}$ \\
\hline $\mathrm{HI}$ & $16.9017^{\mathrm{a}}$ & $8.5560^{\circ}$ & $25.0090^{\mathrm{a}}$ & $7.7620^{\mathrm{a}}$ \\
\hline \multicolumn{5}{|c|}{ Child } \\
\hline $\mathrm{Pb}$ & $49.6012^{a}$ & $24.3799^{a}$ & $73.5756^{a}$ & $22.7422^{a}$ \\
\hline $\mathrm{Zn}$ & $0.2950^{6}$ & $0.2538^{6}$ & $0.2899^{b}$ & $0.1893^{\mathrm{a}}$ \\
\hline $\mathrm{Cr}$ & $0.0719^{b}$ & $0.0232^{b}$ & $0.0820^{b}$ & $0.0388^{\mathrm{b}}$ \\
\hline $\mathrm{Cd}$ & $0.0755^{b}$ & $0.0452^{b}$ & $0.1034^{b}$ & $0.0129^{6}$ \\
\hline $\mathrm{HI}$ & $50.0456^{\mathrm{a}}$ & $24.7022^{\mathrm{a}}$ & $74.0510^{\mathrm{a}}$ & $22.9831^{\mathrm{a}}$ \\
\hline \multicolumn{5}{|c|}{ Southwestern Region } \\
\hline \multicolumn{5}{|c|}{ Adult } \\
\hline $\mathrm{Pb}$ & $5.7020^{\mathrm{a}}$ & $1.4808^{\mathrm{a}}$ & $3.8963^{\mathrm{a}}$ & $2.9775^{\mathrm{a}}$ \\
\hline $\mathrm{Zn}$ & $0.0486^{b}$ & $0.0429^{b}$ & $0.0575^{b}$ & $0.0460^{\mathrm{b}}$ \\
\hline $\mathrm{Cr}$ & $0.0107^{b}$ & $0.0039^{6}$ & $0.0114^{6}$ & $0.0056^{6}$ \\
\hline $\mathrm{Cd}$ & $0.0045^{b}$ & $0.0030^{6}$ & $0.0091^{b}$ & $0.0091^{b}$ \\
\hline $\mathrm{HI}$ & $5.7640^{\mathrm{a}}$ & $1.5306^{\mathrm{a}}$ & $3.9743^{\mathrm{a}}$ & $3.0381^{\mathrm{a}}$ \\
\hline \multicolumn{5}{|c|}{ Child } \\
\hline $\mathrm{Pb}$ & $24.3169^{\mathrm{a}}$ & $6.3150^{\mathrm{a}}$ & $16.6161^{\mathrm{a}}$ & $12.6979^{\mathrm{a}}$ \\
\hline $\mathrm{Zn}$ & $0.1997^{b}$ & $0.1831^{b}$ & $0.2454^{b}$ & $0.1961^{b}$ \\
\hline $\mathrm{Cr}$ & $0.0455^{b}$ & $0.0164^{b}$ & $0.0485^{b}$ & $0.0238^{b}$ \\
\hline $\mathrm{Cd}$ & $0.0194^{b}$ & $0.0129^{b}$ & $0.0388^{b}$ & $0.0388^{b}$ \\
\hline $\mathrm{HI}$ & $24.5815^{\mathrm{a}}$ & $6.5274^{a}$ & $16.9487^{\mathrm{a}}$ & $12.9565^{\mathrm{a}}$ \\
\hline
\end{tabular}

KEY: HI = Hazard index (summation of individual target hazard quotients for different contaminants. Superscripts $(a, b)$ indicate non-carcinogenic effects i.e. $a=$ level of health concern, $b=$ no health concern.

\section{Discussion}

The grasshopper business was mainly dominated by adult men with little to no experience in the food handling business (Table 1). These findings re-emphasize the popularity of edible grasshoppers in Uganda that efforts to commercialize these as food products are in advanced stages $^{15}$, although information on the food safety status of grasshoppers has not been fully evaluated in previous studies in Uganda ${ }^{14,16}$. As demonstrated in the current study, processing, storage and effective handling are major challenges that the communities face, and work on addressing these limitations would be challenged by the increased liberalization of food products ${ }^{16}$. Despite advances in food science research in Uganda, the ability of the local Ugandan population to process grasshoppers effectively has not been exploited fully, showing key challenges in the translation of academic research into field work probably due to limited funding and infrastructure support. In the current study, we demonstrated that grasshoppers are commonly eaten in sub-Saharan Uganda (Figure 1 and Table 2) and this was in agreement with previous reports which had only placed emphasis on central Uganda ${ }^{15,16}$. The eating of grasshoppers, just like other insects ${ }^{17}$ sheds light on the food safety challenges facing a majority of developing countries, since health risks accumulated following chronic exposure to chemical contaminants would ultimately affect human health (Figure 2). This would inevitably create unnecessary strain on 
an already struggling healthcare system ${ }^{1,2}$, demonstrating the wisdom in establishing strong food safety systems for routine screening, safety evaluation of food products in Uganda.

The study showed that catalase was the most abundant antioxidant in the grasshoppers of Uganda and this was found to be highly concentrated in the heads of the grasshoppers (Table 3). This results from the highly abundant forage in the study area, coupled with plenty of water since Uganda lies in the great lakes region. The forage was highly succulent during this study period and the pro-oxidants accumulated were acquired from the plants the insects feed on ${ }^{31,32}$. In Uganda, the Central region has a very high land cover has compared to southwestern Uganda ${ }^{33}$ due to variations in the major farming practices and these are responsible for the changes in antioxidant status observed in grasshoppers from each region. This was important since high levels of antioxidants accumulated in the tissues of the grasshoppers are important in offering protection against oxidative stress ${ }^{18}$. Catalase works in synergy to other pro-oxidant enzymes to reduce on the effects of reactive oxygen species, thus justifying the common practice that grasshoppers are cheaper sources of protein and nutrients in Ugandan communities as compared to livestock protein ${ }^{16,17}$. Increased reliance on grasshopper protein by local communities would subsequently be of nutritional benefit, thus promoting nutrient recycling within the ecosystem ${ }^{34}$.

The major environmental pollutant identified in the grasshoppers was $\mathrm{Pb}$, although a majority of inorganic compounds were above international recommended levels in foods of animal origin (Table 4). Its apparent that a majority of animal protein foods in Uganda are contaminated with $\mathrm{Pb}$ since a recent study has demonstrated high $\mathrm{Pb}$ concentrations in milk and beef ${ }^{14}$, demonstrating the importance of promoting ecosystem protective measures to promote food safety. Accumulation of high $\mathrm{Zn}$ levels in the heads of grasshoppers had been demonstrated earlier by other researchers ${ }^{35}$, however, this was the first study in which high levels of $\mathrm{Pb}$ which carries a higher carcinogenic risk than zinc have been detected in grasshoppers which are consumed by the general population in the East African community ${ }^{16}$. Observations in the study showed that grasshoppers in central Uganda are heavily contaminated with $\mathrm{Pb}$, probably due to high bioaccumulation in the grasshopper tissues following a heavy feeding season due to plenty of forage in the region ${ }^{33}$. Vegetation in Uganda often gets exposed to $\mathrm{Pb}$ through the on-going irrational usage of pesticides showing that findings in this study are of public health importance since central Uganda is home to major business centers in the country due to an increased risk of $\mathrm{Pb}$ contamination in the Ugandan population following consumption of grasshoppers. Bearing in mind that heavy metals have already been isolated from a majority of commercial pesticides $^{3-6}$, government environmental protection strategies $^{6,7}$ which promote ecosystem health would be promoted to reverse the current trend of events in Uganda. A linear relationship was established in the antioxidant and heavy metal concentrations in grasshoppers of central Uganda demonstrating the vicious cycle created in the tissues following a buildup of reactive oxygen species due to high inorganic concentrations in the tissues. In addition, the study used wild grasshoppers as indicators of environmental contamination since these are common in several Ugandan communities ${ }^{31}$. The grasshopper heads have been shown to have high levels of nutritious oils ${ }^{16}$, however, the current study demonstrates that these are major sites for $\mathrm{Pb}$ accumulation, and the threat of bioaccumulation in man is a real threat for all communities which feed on them ${ }^{16,17,22}$.

Food safety analysis was mainly affected by the high EDI $\mathrm{Pb}$ concentrations (Table 5). Increased human consumption of $\mathrm{Pb}$ through the grasshoppers would subsequently predispose the Ugandan community to cancer ${ }^{14}$. The incremental lifetime cancer risk (ILCR) for a Ugandan adult population showed was 100 times above the acceptable limits demonstrating the health hazard of grasshopper consumption (Table 6). Consumption of grasshopper heads would triple the risk than eating abdomens, showing that grasshoppers carry a long-term carcinogenic potential and this risk was higher in children than in adults. These findings show that cancer in Uganda would be on the increase in grasshopper eating communities showing a need to strengthen food safety systems in Uganda for the promotion of human health ${ }^{23,24}$. The improved policy would subsequently promote international trade following the commercialization of healthy grasshoppers for the local and global markets ${ }^{15,16}$. Finally, the study showed that the $\mathrm{HI}$ was high $(\mathrm{HI}>5)$ showing that the contaminants in Ugandan grasshoppers are extremely high (Table 7), necessitating the authorities to intervene as concentrations are not safe. The pollutants identified in this basic 
study would be responsible for the health concerns raised by the communities (Figure 2), showing a need for further studies with an emphasis on $\mathrm{Pb}$ in other major food products of Uganda. Observations in this study demonstrate a need to spearhead commercial production of grasshoppers against the seasonal harvesting of wild grasshoppers which might be carriers of chemical carcinogens.

\section{Conclusion}

Grasshoppers are an important source of livelihood to the Ugandan community, however, high concentrations of $\mathrm{Pb}$ outweigh their beneficial antioxidant activity. In addition, the heads of grasshoppers were found to concentrate all inorganic compounds higher than the abdomens, demonstrating the wisdom of avoiding grasshopper heads in the general population. Strategies to increase food safety screening in Uganda would provide more information which would guide consumers against the consumption of hazardous foods. This would also guide policymakers and commercial development partners on prospective investment options in the sector.

\section{Competing interests}

Authors declare no competing interests

\section{Author contributions}

All authors contributed equally and approved the manuscript for publication.

\section{Author contributions}

Authors contributed equally and approved the manuscript for publication. K.I.K designed the study. C.N and E.B collected the data. K.I.K, A.O, C.A, S.M, and J.K conducted data analysis and interpretation. K.I.K prepared initial draft while C.N, E.B, C.A, A.O, S.M, and J.K read and approved final version for publication.

\section{Acknowledgments}

Authors wish to acknowledge the support offered by the Faculty at the Toxicology Laboratory of the Graduate School of Veterinary Medicine at Hokkaido University (Japan) for the technical insight and positive criticism during the manuscript writing of this work.

\section{Funding}

No funding was acquired for this work.

\section{References}

1 A. Mills, "Health Care Systems in Low- and Middle-In- come Countries," N. Engl. J. Med., vol. 370, no. 6, pp. 552-557, 2014.

2 P. J. Landrigan and R. Fuller, "Environmental pollution: An enormous and invisible burden on health systems in low- and middle-income counties.," World Hosp. Health Serv., vol. 50, no. 4, pp. 35-40, 2014.

3 D. L. Shaner and H. J. Beckie, "The future for weed control and technology," Pest Management Science, vol. 70, no. 9. pp. 1329-1339, 2014.

4 H. Kraehmer, B. Laber, C. Rosinger, and A. Schulz, "Herbicides as weed control agents: state of the art: I. Weed control research and safener technology: the path to modern agriculture.," Plant Physiol., vol. 166, no. 3, pp. 1119-31, 2014.

5 S. Kelemu et al., "African edible insects for food and feed: inventory, diversity, commonalities and contribution to food security," J. Insects as Food Feed, vol. 1, no. 1, pp. 1-17, 2015.

6 E. Gimeno-García, V. Andreu, and R. Boluda, "Heavy metals incidence in the application of inorganic fertilizers and pesticides to rice farming soils," Environ. Pollut., vol. 92, no. 1, pp. 19-25, 1996.

7 Z. Atafar et al., "Effect of fertilizer application on soil heavy metal concentration," Environ. Monit. Assess., vol. 160, no. 1-4, pp. 83-89, 2010.

8 J. Yabe, M. Ishizuka, and T. Umemura, "Current levels of heavy metal pollution in Africa.," J. Vet. Med. Sci., vol. 72, no. 10, pp. 1257-1263, 2010.

9 M. R. Abraham and T. B. Susan, "Water contamination with heavy metals and trace elements from Kilembe copper mine and tailing sites in Western Uganda; implications for domestic water quality," Chemosphere, vol. 169, pp. 281-287, 2017.

10 M. S. Lwanga, F. Kansiime, P. Denny, and J. Scullion, "Heavy metals in Lake George, Uganda, with relation to metal concentrations in tissues of common fish species," Hydrobiologia, vol. 499, pp. 83-93, 2003.

11 A. Tamale et al., "Mercury concentration in muscle, belly fat and liver from Oreochromis niloticus and Lates niloticus consumed in Lake Albert fishing communities in Uganda," Cogent Food Agric., vol. 93, no. just-accepted, pp. 1-10, 2016.

12 P. Ogwok, M. Bamuwamye, G. Apili, and J. H. Musalima, "Health Risk Posed by Lead, Copper and Iron via Consumption of Organ Meats in Kampala City ( Uganda )," J. Environ. Pollut. Hum. Heal., vol. 2, no. 3, pp. 69-73, 2014.

13 M. Bamuwamye, P. Ogwok, and V. Tumuhairwe, "Cancer and Non-cancer Risks Associated With Heavy Metal 
Exposures from Street Foods : Evaluation of Roasted Meats in an Urban Setting," J. Environ. Pollut. Hum. Heal., vol. 3, no. 2, pp. 24-30, 2015.

14 K. I. Kasozi, P. C. Natabo, S. Namubiru, D. S. Tayebwa, A. Tamale, and P. H. Bamaiyi, "Food Safety Analysis of Milk and Beef in Southwestern Uganda," J. Environ. Public Heal., vol. 2018, p. 7, 2018.

15 G. N. Agea, J.G. Biryomumaisho, D. Buyinza, M. Nabanoga, "Commercialization of Ruspolia nitidula (Nsenene grasshoppers) in central Uganda," African J. Food Agric. Nutr. Dev., vol. 8, no. 3, pp. 291-303, 2008.

16 G. Ssepuuya, I. M. Mukisa, and D. Nakimbugwe, "Nutritional composition, quality, and shelf stability of processed Ruspolia nitidula (edible grasshoppers)," Food Sci. Nutr., vol. 5, no. 1, pp. 103-112, 2017.

17 D. Sun-Waterhouse et al., "Transforming insect biomass into consumer wellness foods: A review," Food Res. Int., vol. 89, pp. 129-151, 2016.

18 R. V. Barbehenn, "Gut-based antioxidant enzymes in a polyphagous and a graminivorous grasshopper," J. Chem. Ecol., vol. 28, no. 7, pp. 1329-1347, 2002.

19 R. V Barbehenn, "Antioxidants in Grasshoppers : Higher Levels Defend the Midgut Tissues of a Polyphagous Species Than a Graminivorous Species," J. Chem. Ecol., vol. 29, no. 3, pp. 683-702, 2003.

20 N. J. Turner et al., "Edible and Tended Wild Plants, Traditional Ecological Knowledge and Agroecology," CRC. Crit. Rev. Plant Sci., vol. 30, no. November, pp. 198 225, 2011.

21 M. Augustyniak, A. Babczynska, and M. Augustyniak, "Does the grasshopper Chorthippus brunneus adapt to metal polluted habitats? A study of glutathione-dependent enzymes in grasshopper nymphs," Insect Sci., vol. 16, no. 1, pp. 33-42, 2009.

22 M. Augustyniak, J. Juchimiuk, W. J. Przybyłowicz, J. Mesjasz-Przybyłowicz, A. Babczyńska, and P. Migula, "Zinc-induced DNA damage and the distribution of metals in the brain of grasshoppers by the comet assay and micro-PIXE," Comp. Biochem. Physiol. - C Toxicol. Pharmacol., vol. 144, no. 3, pp. 242-251, 2006.

23 C. Malakar, A. Ganguly, and P. Haldar, "Influence of Cadmium on Growth, Survival and Clutch Size of A Common Indian Short Horned Grasshopper , Oxya fuscovittata," Am. J. Toxicol. Sci., vol. 1, no. 1, pp. 32-36, 2009.

24 E. Warchałowska-Śliwa, M. Niklińska, A. Görlich, P.
Michailova, and E. Pyza, "Heavy metal accumulation, heat shock protein expression and cytogenetic changes in Tetrix tenuicornis (L.) (Tetrigidae, Orthoptera) from polluted areas," Environ. Pollut., vol. 133, no. 2, pp. 373-381, 2005.

25 L. Flohé and W. A. Günzler, "Assays of glutathione peroxidase," Methods Ensymol., vol. 105, no. July, pp. 114 120, 1984.

26 P. Monostori, G. Wittmann, E. Karg, and S. Túri, "Determination of glutathione and glutathione disulfide in biological samples: An in-depth review," Journal of Chromatography B: Analytical Technologies in the Biomedical and Life Sciences, vol. 877, no. 28. pp. 3331-3346, 2009.

27 L. H. Johansson and L. a Borg, "A spectrophotometric method for determination of catalase activity in small tissue samples.," Anal. Biochem., vol. 174, no. 1, pp. 331-6, 1988.

28 R. Kopl, "Atomic spectrometry Atomic absorption spectrometry ( AAS )," Adv. Strateg. food Anal. At., pp. 1-15, 2013.

29 World Bank, "The World Bank DataBank," Data Bank, 2016. .

30 J. Shargorodsky, S. G. Curhan, E. Henderson, R. Eavey, and G. C. Curhan, "Heavy metals exposure and hearing loss in US adolescents.," Arch. Otolaryngol. Head. Neck Surg., vol. 137, no. 12, pp. 1183-9, 2011.

31 Z. Zhang, Q. Wang, D. Zheng, N. Zheng, and X. $\mathrm{Lu}$, "Mercury distribution and bioaccumulation up the soil-plant-grasshopper-spider food chain in Huludao City, China," J. Environ. Sci., vol. 22, no. 8, pp. 1179-1183, 2010.

32 Y. Zhang et al., "Chronic accumulation of cadmium and its effects on antioxidant enzymes and malondialdehyde in Oxya chinensis (Orthoptera: Acridoidea)," Ecotoxicol. Environ. Saf., vol. 74, no. 5, pp. 1355-1362, 2011. 33 J. Pender, P. Jagger, E. Nkonya, and D. Sserunkuuma, "Development pathways and land management in Uganda," World Dev., vol. 32, no. 5, pp. 767-792, 2004.

34 A. Gmuer, J. Nuessli Guth, C. Hartmann, and M. Siegrist, "Effects of the degree of processing of insect ingredients in snacks on expected emotional experiences and willingness to eat," Food Qual. Prefer., vol. 54, pp. 117-127, 2016.

35 B. Devkota and G. H. Schmidt, "Accumulation of heavy metals in food plants and grasshoppers from the Taigetos Mountains, Greece," Agric. Ecosyst. Environ., vol. 78 , no. 1 , pp. $85-91,2000$. 